\title{
ベ口毒素生産性大腸菌0157の 有機酸耐性
}

\author{
山篠貴史 ${ }^{* 1}$, 太田美智男*2 \\ ${ }^{* 1}$ 名古屋大学大学院生命農学研究科, ${ }^{* 2}$ 名古屋大学大学院医学研究科
}

\section{7 による感染症}

\section{1．宿主と寄生体，非病原性細菌と病原性細菌}

我々ヒトの肉眼では見ることができない多種多数の微 生物 (microbe) が常に存在しているが，その数は $10^{14}$ cfu（コロニー形成単位：colony forming unit）に上る といわれる。ヒトを構成する全細胞数が約 $10^{13}$ 個と見 積もられていることから，ヒトには自分自身を構成する 細胞数に比して，その 10 倍の数の微生物が常在してい るということになる．これらのほとんどは常在性の菌類 であることから常在菌といわれる．常在菌といえども宿 主 (host) に対する寄生体 (parasite)である以上，宿主と 寄生体との間には何らかの宿主-寄生体相互関係 (hostparasite relationship）が成立しており，互いに影響を 与えあっている．今日でも宿主-寄生体相互関係を詳細 に理解することは未だ困難であり, 常在菌は宿主に対し てあらゆる面を考慮すれば無害であるとはいいきれない が，通常害を及ぼすことはないと考えられている．本稿
で取り上げる大腸菌も，ヒトを含む動物の腸管内におけ る常在菌であり, 腸管内では害を与えるどころか, むし ろ宿主にとって好都合な消化吸収，ビタミン合成，異物 代謝などの重要な役割に預かることが知られている。と ころが同じ大腸菌でも，本来の住処である腸管内で，こ れが原因で腹痛・下痢などを主症状とする腸管感染症を ひき起こす一群が存在する。これらは下痢原性大腸菌あ るいは広義の腸管病原性大腸菌と呼ばれ，一般の大腸菌 と区別されている．詳しく言及しないが，下痢原性大腸

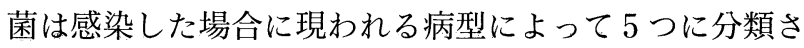
れる。これらに共通する重要な特徵は，宿主に定着でき る能力を保持していることである。ここでいう定着 (colonization) とは，細菌が感染局所に到着し，目的と する細胞に付着 (adhesion)して増殖する現象と定義す ることができ，病原体が定着に成功した時点をもって感 染の成立とみなすことができる，感染が成立した場合に 現われる病型の多様性は, 大腸菌側の宿主への定着戦略 の違いにより生ずると理解することが可能である. 


\section{2. ベロ毒素産生性大腸菌 0157 とは}

今から 7 年前の 1996 年, 大腸菌 0157 による食中毒 が日本全国に猛威をふるったことは記憶に鮮明である. O157 は過去にも大規模な集団感染をもたらしたことが あり，1982 年に米国のオレゴン州とミシガン州で発生 した集団下痢症事件を契機として，世界的に注目される ようになったＯ１57 はまさしく下痢原性大腸菌である。 その中での病型による分類としては，この菌による感染 症の典型的臨床像が出血性大腸炎であったことから，当 時, 腸管出血性大腸菌 (Enterohemorrhagic E. coli; EHEC）と称された。しかしその後の検討で, EHEC の病原毒素がべロ毒素(Vero-cytotoxin；VT)であるこ と，その病像も出血性下痢とは限らないことなどが明ら かにされたことから，最近ではVTを産生する大腸菌 全体を広くべロ毒素産生性大腸菌（VT producing E. coli ; VTEC) と総称している.べロ毒素は, 1977 年に カナダの Konowalchuk らが，子供の下痢症から分離 された大腸菌の一部が，アフリカミドリザルの腎臓由来 細胞であるべロ細胞に対して毒性を示す新しい細胞毒素 として最初に発見したものである(1).

O157 を光学顕微鏡で観察しても，形態的に他の大腸 菌と特に違いは認められない. 光学顕微鏡では観察でき ないが，一般に大腸菌を含むグラム陰性細菌の菌体表層 からは，糖鎖が伸張しており表層全体を覆っている。そ の実体は糖脂質である LPS（lipopolysaccharide：リ ポ多糖，内毒素ともいう）である(図 6 参照)。LPS は 外膜自身の構成要素であり，菌体側基部にあたるリピド $\mathrm{A}$ と呼ばれる疎水的な部分と菌体外へ伸びる親水的な 多糖部分から成っている。ささらに，多糖部分は基部に近
い側から菌種間で比較的普遍的なオリゴ糖の部分（コア オリゴ糖 (core OS) と呼ばれ, 基部に近い側の内部コア オリゴ糖(inner core OS) と基部から遠い側の外部コア オリゴ糖(outer core OS)から成る) と，菌種によって糖 質の構成が異なるオリゴ糖の繰り返し部分 $(\mathrm{O}$-糖鎖) か ら成る。後者は菌種の違いを反映する表層抗原に相当す る $\mathrm{O}$ 抗原となる部分であり，ここが $\mathrm{O}$ 抗原糖鎖と呼ば れる所以である. 0157 とは大腸菌の血清型のことで, $\mathrm{O}$ 抗原型が 157 であることを意味している.

\section{0157 感染症の特徵}

大規模な集団感染後，大腸菌 $\mathrm{O} 157$ を含むべ口毒素産 生性大腸菌による出血性下痢症とそれに伴う脳症，溶血 性尿毒症症候群(HUS) は一向に減少しない。ヒトから ヒトへ感染することから指定伝染病扱いになり，すべて の件数を届け出ることとなって，ある程度正確な患者数 が把握されている，週ごとの発生動向の菌株集計(図 1) では，1997 年から 2002 年の発生傾向は毎年よく似てい る.すなわち，患者数は夏場に多く冬季には減少する. より重要なことは，毎年 $2 \sim 3$ 千人の患者が発生し続け ていることである。これまでのVTECによる感染症発 生事例の動向調査から浮かび上がってきた 0157 の特徴 は次の 3 つである.

(1)食中毒を起こした食品中の残存菌量の測定や水系感 染（具体的にはプールでの感染など）も存在したという 事例から，感染が比較的少数の菌で起こる（一般に食中 毒は 10 万〜 100 万 $\mathrm{cfu}$ の生菌を摂取しなくては起こら ないが，0157 の場合は 100～1000 cfu で感染するとい われる)。

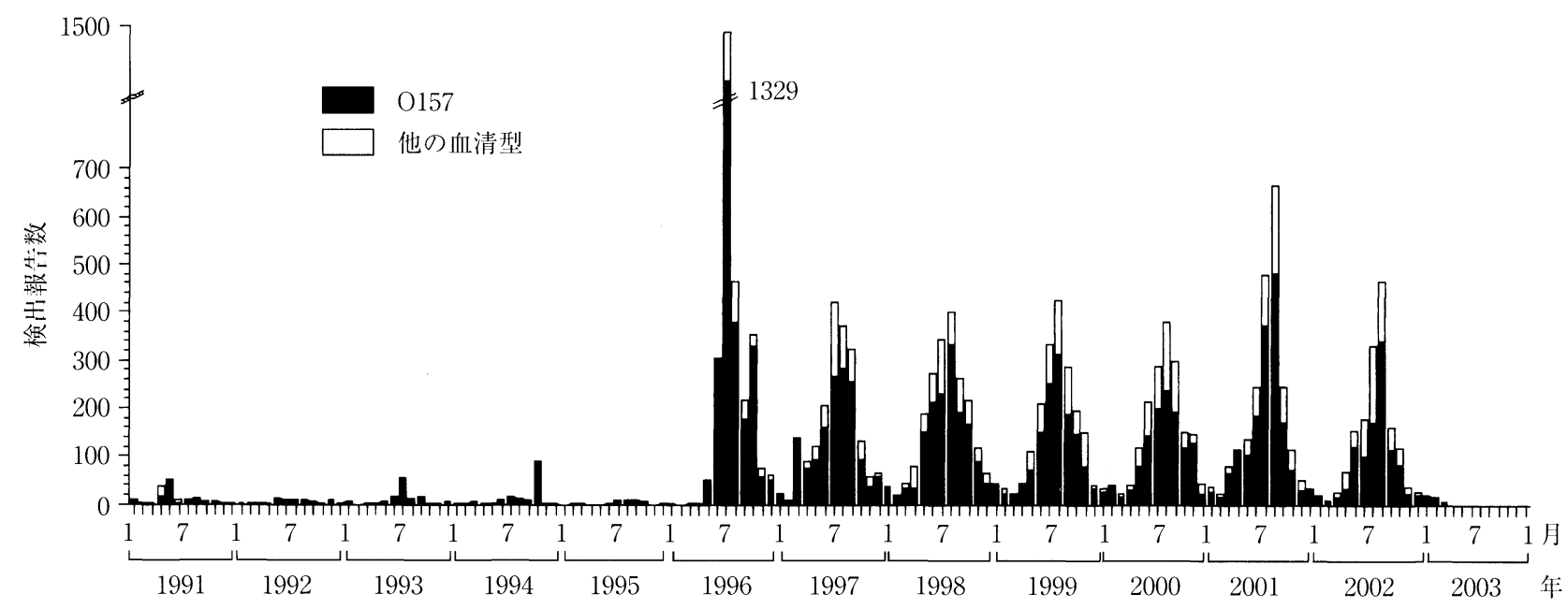

図 1 -ベロ毒素産生性大腸菌月別検出状況（1991 年 1 月～2003 年 3 月）

各都道府県市の地方衛生研究所からの検出報告を示した。国立感染症研究所病原微生物検出情報: 2003 年 4 月 23 日現在報告数。 (http: //idsc.nih.go.jp/prompt/graph/vt9j.gif)より引用. 
(2) 1996 年 7 月に堺市の小学校, 病院, 老人ホームな どで患者数が 100 名を越える集団感染が起こったという 事例が少なくないことからもわかるように, 他の病原菌 による食中毒と比較しても大規模な発生が多い.

(3)分離されてくるVTECの血清型は, O157 を精度 よく検出できるキットが発達しているためでもあるが, $\mathrm{O} 157$ が圧倒的に多い.

これらの事実は, 0157 の感染力の高さを物語ってい ると同時に, $\mathrm{O} 157$ が我々にとって比較的身近な生活環 境中で生存していることを示すものである. 具体的には 日本の乳牛の $70 \%$ VTEC を保菌しているという結 果が出ており ${ }^{(2)}$, 自然界での VTEC 保菌動物が家畜に まで及んでいることを考慮すると, ここから食水系が污 染されることでヒトに経口感染するという可能性が考え られる. 食品中の 0157 の生存能力に関しては, ソーセ

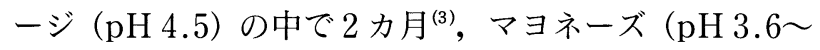
3.9）の中で数週間(4)，アップルソーダ（pH 3.6〜4.0） の中で 1 力月 ${ }^{(5)}$ という検查結果が報告されている. 今後 種々の局面でより適切に 0157 の安全性を検定し, 効果 的な予防手段を考案する必要があろう。 また， 0157 の 感染力の強さを理解することも重要である. そのために は, 0157 の環境中（宿主体内も含む）での生存能力の 高さを解析・検討することが重要であると筆者らは考 え, 数年前から研究を開始した。本稿では, 筆者らが解 析した 0157 の酸而性を中心に紹介する.

\section{極端な低 $\mathrm{pH}$ 環境下で生存する能力}

\section{1. 酸耐性とは}

病原性の腸内細菌が腸管感染を起こすためには, まず 生きて腸管にたどり着くことが前提条件になる. その過 程で経る第一の試練は, 胃の中で分泌される胃酸に抗し て数時間堪え忍ぶことである．このことを考慮して，多 くの研究者は, 極端に低い $\mathrm{pH}$ 環境下 $(\mathrm{pH}<3)$ で数時 間生存できる能力を指標に酸耐性能力を検定することに している. 今やDNA の組換えやタンパク質の発現など で分子生物学研究の担い手として必要欠くべからざる存 在である大腸菌の実験室株は, 通常, 対数増殖期 ( $\log$ phase）には pH 3 末満の条件では数時間ともたずに死 滅していく，具体的には，塩酸を用いて Luria-Bertani (LB) 培地を $\mathrm{pH} 2.0$ に調製した培地中に, 対数増殖期に ある大腸菌 $\mathrm{K}-12$ 株由来の $\mathrm{MC} 4100$ を $2 \times 10^{6} \mathrm{cfu} / \mathrm{ml}$ の 菌密度で存在させて $37^{\circ} \mathrm{C} て ゙$ 静置させておくと, 3 時間後 には生存率が $0.01 \%$ \%下になってしまう.この条件で は $10,000 \mathrm{cfu}$ の大腸菌がことごとく死滅し, わずかに 1 cfu 生き残れるかどうかということになる.ところが, 大腸菌をあらかじめ穏やかな酸性条件 $(\mathrm{pH} 5.5 \sim 6.0)$ で 数時間培養しておくと, $\mathrm{pH} 2.0$ における生存率が $1 \%$ 以 上に上昇する (順応) ことが知られている。 また，培地 の栄養源が枯渴するなどの原因で静止期（stationary phase）にある大腸菌は, 秪やかな酸性条件で順応させな くても, pH 2.0 に曝して 3 時間経過後も $10 \%$ 以上の生 存率で生き残る。つまり，酸耐性が普段の 100〜1000 倍 以上に上昇している.このことから, 酸耐性能力は順応 後や静止期に発現誘導されるものであることがわかる. 細菌細胞が自身の生理的・形態的状態を可逆的に変化さ せ，種々の環境ストレスに臨機応変に適応できる能力を 保持していることは大変よく知られている。低 $\mathrm{pH}$ スト レスに関しても，同じ細菌が酸に対して無防備な細胞か ら耐性を備えた細胞に可逆的に変化することで適応でき るわけである.

\section{2. 酸而性機構}

それでは, 酸耐性能力を発揮している細胞ではいかな る機構が発現しているのであろうか. 残念ながら, 肝心 の酸耐性機構は現在十分にはわかっていないが, 複数の 機構が関与していることが知られている。重要な事実と しては，上記の条件での酸而性が培地中のグルタミン酸 の存在に依存しているということである。 それに関連し て, 酸性条件や静止期には, 大腸菌のグルタミン酸 $\alpha-$ デカルボキシラーゼ(GAD : GadA と GadB の 2 つの イソ酵素が存在する) と, その基質/生成物の対向輸送 （具体的には，GADの基質であるグルタミン酸の細胞 内への取り込みと生成物の一つである $\gamma$-アミノ酪酸 $(\mathrm{GABA})$ の細胞外への排出を同時に行なう（アンチポ ート輸送)）活性をもつと推定されているアンチトラン スポーター（GadC）の働きにより, 細胞内でグルタミ ン酸の $\alpha$-カルボキシル基を連続的に脱炭酸する系が誘 導・構成されることが知られている ${ }^{(6,7)}$. この系が働か ない $\operatorname{gad} A / B$ 二重変異株や $\operatorname{gad} C$ 変異株では酸耐性能 力を失うことから, 細胞質内グルタミン酸連続脱炭酸 反応系は酸耐性機構の一部を担っているといえる.さら に, $\mathrm{ClC}$ 型アニオンチャネルをコードしている遺伝子 yadQ, ynfJ の二重欠失変異株では, グルタミン酸に依 存した酸耐性が有意に減少してしまうことが最近報告さ れた ${ }^{(8)}$.この結果は, 細胞内でグルタミン酸脱炭酸反応 が連続的に起こるためには, 細胞質膜を通過するアニオ ンの移動を伴うことが必要であることを示している.

推測の域を出ないが, $\alpha$-カルボキシル基が脱プロト ン化したグルタミン酸（電荷は一-1または 0 ）が，選択 
的または特異的に GadC により認識されて細胞内に取 り込まれ，他の解離基は変化しないという仮定の下で, 基質と脱炭酸反応生成物 GABA（グルタミン酸の電荷 がー 1 または 0 に対応してそれぞれ電荷 0 または +1$)$ が細胞内外で交換されるというサイクルを繰り返すと, 細胞内のプロトンが消費されていくことになる，その結 果, 細胞内外の電位差が大きくなってしまうが，細胞内 アニオン（塩化物イオンが有力と考えられている）が $\mathrm{ClC}$ 型チャネルを通って細胞外へ流出することで, 細胞 外低 $\mathrm{pH}$ 条件下においても膜電位を適切に調節しなが ら細胞内 $\mathrm{pH}$ を適切に維持できるというモデルが提唱 されている(図 2)。ただし，細胞内のプロトンを消費す ることが直接酸耐性に結びついているとは即断できな い. 千葉大の Kobayashiによって最初に主張された 説 ${ }^{(9,10)}$ である，脱炭酸反応で生成される二酸化炭素が酸 性条件に扔ける炭酸の供給源として生理的に必須な反応 だとする考え方も重要である，大腸菌のプロトン（水素 イオン: $\left.\mathrm{H}^{+}\right)$の膜透過性は約 $0.002 \mathrm{H}^{+} \mathrm{mmol} / \mathrm{pH} /$ 秒/ $\mathrm{g}$ タンパク質という測定結果が存在する。したがって, 細胞の内外に 10 倍（1 pH 分）のプロトン濃度差があ った場合には，菌の濃度を $1 \mathrm{~g} / l$ とすると，プロトンの 進入をうち消すためには毎分 $0.12 \mathrm{mmol} / l$ のアミノ酸 を脱炭酸する必要があるということもその根拠となって いる.

上記の機構とは独立に，酸耐性に必須の遺伝子として $h d e A$ 遺伝子が知られている ${ }^{(11,12)}$. この遺伝子の欠失変 異株は静止期に酸耐性を示さなくなる，産物である HdeA は酸性条件や静止期に発現し，ペリプラズム (外膜と細胞質膜との間の空間) に分泌されるタンパク

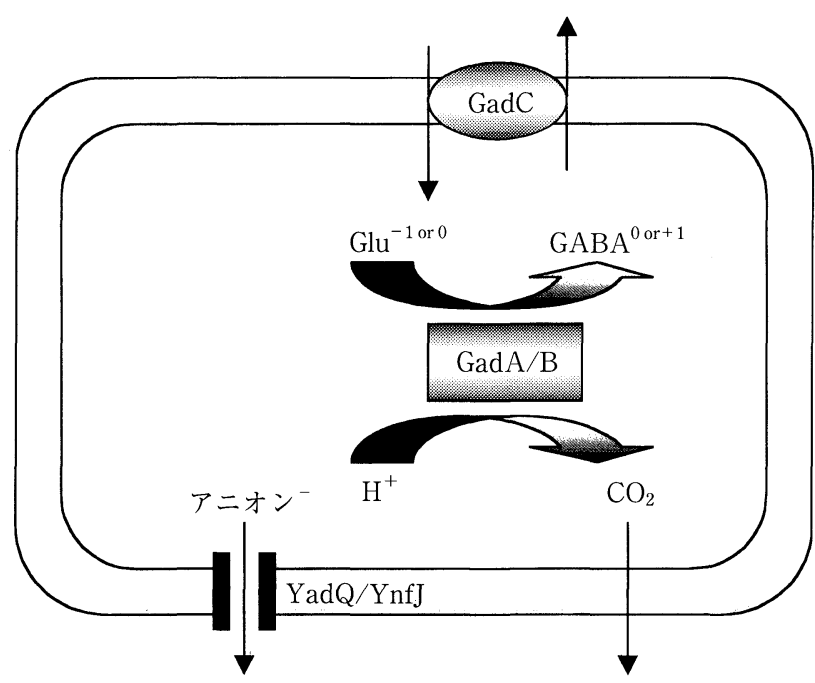

図 2 ログルタミン酸連続脱炭酸反応系による酸耐性機構の モデル
質で，プロセシング後の成熟型タンパク質の分子量は $9.7 \mathrm{k}$ と小さい. 最近報告された X 線結晶構造解析の結 果から， 4 本の $\alpha$-ヘリックスから成る単一ドメインの タンパク質として 3 次元構造が明らかにされてい $ろ^{(12,13)}$. 生化学的な解析から,このタンパク質は通常 2 量体として存在し, 酸性条件で単量体になる性質をもつ こと，酸性条件下におけるタンパク質の変性を抑制でき る活性をもつことが報告されている。したがって, HdeA は低 $\mathrm{pH}$ 条件でペリプラズムにおける分子シャ ペロン様の機能をもつことが推定される(12).

現在, 生理的な条件で発現誘導される酸而性機構は, 上記のグルタミン酸に依存したグルタミン酸連続脱炭酸 反応系と, HdeAによるシャペロン様活性という, 少 なくとも 2 つの独立した生化学反応系がわかってきてい るにすぎないが，実際にはこれ以外に数多くの酸耐性遺 伝子が存在していると考えられている. さらに，臨床分 離株は実験室株よりも酸而性能が高いのではないかと指 摘され, 実験室株がもっている以上の酸耐性機構を備え ている可能性が存在する. しかし，これまでに 0157 を 含む大腸菌, サルモネラ菌, 赤痢菌で酸耐性能の高い臨 床分離株が存在するということは報告されているもの の, これらの病原性腸内細菌に特異的に備わっている酸 耐性機構は見いだされていない.

\section{3. 酸耐性機構の誘導}

酸而性遺伝子が発現し酸而性機構が細胞に備わること で, 非酸而性から酸而性へと細胞の性質が可逆的に変化 することはすでに述べた，したがって，臨床分離株と実 験室株との間で酸耐性機構そのものは共通であったとし ても，酸而性機構を誘導する情報伝達系に違いがあると いう可能性を考えることはできる.酸耐性遺伝子 $\operatorname{gad} A, \operatorname{gadBC}, h d e A$ の発現は, 穏やかな酸性条件や 静止期に誘導されるが，この誘導はシグマ因子 $\sigma^{\mathrm{s}} に$ に依 存している ${ }^{(14)}$. 大腸菌のシグマ因子は, RNA ポリメラ 一ゼホ口酵素 $\left(\alpha \alpha \beta \beta^{\prime} \sigma\right)$ を構成しているサブユニットの 一つで，転写開始段階におけるプロモーター認識に必須 の要素である. 大腸菌には 7 種類のシグマ因子が存在す ることが知られて抢り，これらが RNA ポリメラーゼに よるプロモーター認識の特異性を変化させることによ り, 遺伝子発現様式が大幅に変化すると考えられてい る(15). 中でも $\sigma^{\mathrm{s}}$ は, その細胞内存在量が種々のストレ ス条件に応答して増加することが知られており，ストレ 大応答型のシグマ因子として広範な遺伝子発現制御に関 わっていると考えられている(16)。したがって，ストレ ス環境下で獲得される酸耐性は，ストレス環境下で特異 
的に発現する $\sigma^{\mathrm{s}}$ の働きによって誘導されると理解する ことができる.

一方，ストレスのない環境下においても，人工的に転 写制御因子を過剰発現させることで酸耐性を誘導できる ことが報告されている。詳述はしないが, 二成分制御系 を構成するレスポンスレギュレーターの NarL ファミリ 一に属する転写調節因子 EvgAの過剰発現体では, AraC/XylS ファミリーに属する転写制御因子 $\mathrm{YdeO}$ お よび LuxR スーパーファミリーに属する転写制御因子 YhiE を介して酸耐性遺伝子が発現し, 酸耐性能をもつ ようになるという結果が最近報告されている(17).また， AraC/XylS ファミリーに属する転写制御因子 $\operatorname{GadX}$ お よび GadW により, gadA, $\operatorname{gad} B C, h d e A B$ などの発現

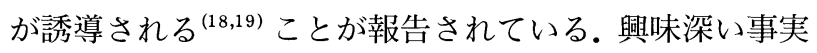
として, エルシニア属菌 (Yersinia enterocolitica) の病 原性に必須の転写制御因子である RovA と高い相同性 をもつSlyA タンパク質をコードする遺伝子が, 0157 を含む病原性大腸菌やサルモネラ菌に存在しており, こ の遺伝子をもたない大腸菌 K-12 株に導入すると, 酸耐 性遺伝子を含む病原因子が誘導されることが判明し た ${ }^{(20)}$. ただし，上記すべての転写因子に関して，K-12 株中でそれらを機能させる生理的シグナルは見いだされ ておらず，生理的な条件で実際にこれらの因子が働いて いるかどうかは不明である.しかし, 野生細菌の実際の 環境応答に関しては, これらの転写制御因子を効果的に 用いて適切に酸耐性遺伝子を誘導することにより酸スト レスに適応しているという可能性はある，実験室株であ る K-12 は slyA 遺伝子を保持していないことから，少 なくともSlyA による酸耐性遺伝子の誘導はこれを保持 する病原性細菌 ${ }^{(21 \sim 24)}$ の酸ストレス応答に重要な役割を 果たしている可能性が考えられる。

\section{0157 の酸耐性}

筆者らは, 1996 年に堺市で大規模な集団食中毒をひき 起こした O157 の臨床分離株（以後 NGY9 と記す）を対 象に酸耐性を調べた。 MC4100の酸耐性能を検定した場 合と同じ条件下でその耐性能力を調べたところ, 対数増 殖期には生存率が $0.01 \%$ 以下と低く, 静止期には生存 率が約 $10 \%$ に昇した。意外なことに，この生存率に より示される 0157 の酸耐性の特徴は MC4100のそれと ほとんど変わらない. 前項で述べたように, NGY9の 酸耐性遺伝子が MC4100 とは一部異なる複数の転写因 子が関与する情報伝達機構により誘導される可能性もあ ったが，対数増殖期の細胞は酸耐性能を誘導できておら ず，静止期の細胞も $\sigma^{\mathrm{s}}$ をコードする $r p o S$ 遺伝子の変
異により，簡単に酸耐性能を失うという結果となった。 このことは, 筆者らの条件では非病原性の大腸菌実験室 株の MC4100 も病原性大腸菌 O157 の NGY9 株も, 極 端に低い $\mathrm{pH}$ で生存できる能力は同じであったことを 意味している。もちろん, 実際の経口感染ルートでは, O157 が体内の特異的なシグナルを認識して酸耐性遺伝 子を効率よく誘導できるのかもしれないし，食品中は試 験管内と異なり，何らかのストレス環境下にあって酸耐 性能がすでに誘導されていた場合も多いのではないかと 考えられる。したがって，0157 が特別に胃での酸耐性 に優れているとは考えにくい.よって, O157の感染に 重要な性質は他にあるのではないだろうかと考えられる (後述).

\section{有機酸存在下で増殖する能力}

1.なぜ有機酸耐性に着目したか

近年日本で多発した腸管出血性大腸菌 O157 による感 染症を契機として，VTECの環境ストレスに対する抵 抗性に多様性があることが相次いで報告され, 野生細菌 の環境ストレス適応機構に関心が寄せられるようになっ てきている．実際，最も被害の大きかった堺市で集団食 中毒の原因となった NGY9 は，特に有機酸に対する抵 抗力が高く, 病原性大腸菌の酸耐性能力と感染後の重症 化との相関関係が示されている. 筆者らも, 当時から NGY9 株の酸耐性能力の高さを感染成立への重要条件 として重視・着目しており, ラットを用いた動物感染モ デルを構築し, 酸耐性能力の異なる種々の株間 ${ }^{(25)}$ にお ける感染性の強さを比較検討してきた。その結果, NGY9 を含む有機酸耐性能力が強い株は消化管病変を 形成するが，有機酸耐性能力が弱い株は消化管病変を形 成しないという傾向が観察された。このことは，消化管 感染に有機酸耐性能力が重要であることを示唆してい る。しかし，胃における有機酸ストレスと考えられる極 端に低い $\mathrm{pH}$ での適応能力は, 試験管内で調べた限り, 先述したようにNGY9 が特に優れているとはいえなか った、そこで, 腸内細菌本来の生息場所である腸管にお ける有機酸耐性能力が重要かどうかを検討することにし た。

大腸菌をはじめとする腸内細菌は，消化管にたどり着 いて初めて増殖を開始することができるが, 腸管内では 酸素濃度がきわめて低いため, 増殖するためのエネルギ 一は糖を代謝して (発酵) 得ている. 大部分の腸内細菌の 発酵様式は混合酸発酵を行なっており, 最終産物として エ夕ノールと乳酸に加え, 短鎖 $\left(\mathrm{C}_{1}, \mathrm{C}_{2}, \mathrm{C}_{3}, \mathrm{C}_{4}\right)$ の低級脂 
肪酸を生成する，その中でも主生成物は短鎖低級脂肪酸 であり, ギ酸, 䣷酸, プロピオン酸, 中でも特に酢酸が 菌体外へ放出される。したがって, 腸管の環境は局所的 にみれば細菌の増殖とともに酸性化していく(pH 4.5〜 6).胃では $\mathrm{pH} 2$ という無機の強酸が存在する環境下で 数時間細胞が生存（survival）し続ける能力が要求され る一方, 腸では弱酸である脂肪酸を主成分とする有機酸 が存在する $\mathrm{pH} 4.5 \sim 6$ の環境下で細胞が効率よく増殖 (proliferation) し続ける能力が要求される.

そこで筆者らは, 試験管内で有機酸ストレス条件下 (12 mM 䣫酸を含む LB 培地に $50 \mathrm{mM}$ の MES (2-morpholinoethanesulphonic acid)を存在させて pH 5.4 に保った）での増殖を調べてみると, 通常の大腸菌は増 殖が顕著に阻害されるが, NGY9 はこの条件でより素早 い増殖が可能であることを見いだした（図 3)。これは， 腸管における酸性かつ低酸素条件下での発酵による増殖 能力の上昇に直結するものである. したがって, 弱酸 (有機酸) が存在する環境下での増殖能力も酸耐性能力 の一環として捉えることが可能であり, それが腸管感染 能力の高さに結びつくほど重要かもしれないことを示唆 している.しかし, 現在までの酸耐性の研究は, 専ら細 胞が増殖不可能な極端に低い $\mathrm{pH}$ 環境（胃）での細胞 の生存能力に焦点があてられており, やや低い $\mathrm{pH}$ 環 境 (腸) での増殖能力については意外にも着眼されてい ない.そこで筆者らは, 有機酸存在下での増殖能力に重 要な役割を果たす機構の解明が必要であると考え, 有機

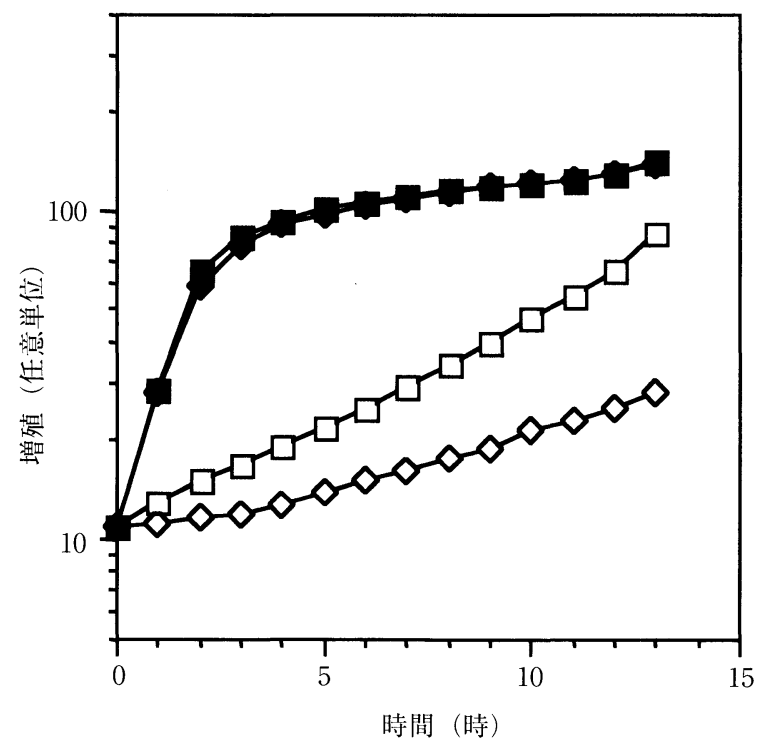

図 3 ・腸菌 K-12 実験室株 MC4100 と大腸菌 0157 臨床分 離株 NGY9 の酢酸存在下での増殖能力の比較

$12 \mathrm{mM}$ 酢酸を含む LB-MES 液体培地 $(\mathrm{pH}$ 5.4) 上での両者の増殖 曲線. $\square: \mathrm{NGY9}, \diamond: \mathrm{MC} 4100, \square: \mathrm{NGY} 9+$ 酢酸培地, $\diamond:$ $\mathrm{MC} 4100+$ 酢酸培地
酸として大腸菌が混酸発酵反応をするときの主生成物で ある酢酸に着目することにした。 以後, 有機酸耐性とい う言葉を用いるが，この耐性とは「酢酸存在下での増殖 能力」という意味で用いている.

\section{2. 有機酸の毒性とは何か}

有機酸は弱酸としての性質をもっており, 水溶液中で プロトン解離型 $\left(\mathrm{RCOO}^{-}\right)$と非解離型 $(\mathrm{RCOOH})$ として 存在する. 解離の割合は水溶液 $\mathrm{pH}$ と弱酸に固有の解 離定数 $\mathrm{p} K_{\mathrm{a}}$ によって規定される. プロトン解離型は親 水性であるため細胞質膜を透過できないが, 非解離型は 疎水性であるため通過できる，細胞質とペリプラズムと の間には水素イオン濃度差が存在し, 細胞内は細胞外よ り水素イオン濃度が低くなっている. よって, 細胞内の 酢酸解離度は細胞外よりも大きくなっているので, 細胞 質膜を透過した有機酸は細胞質でそのほとんどが解離 し, 細胞内の $\mathrm{pH}$ を低下させる(図 4). 具体的に大腸菌 の場合, 培地 $\mathrm{pH}$ 。 が 6.00 , 細胞内 $\mathrm{pH}_{\mathrm{i}}$ は 7.85 である 状態に, 培地の $\mathrm{pH}$ を変えずに酢酸ナトリウムを培地 に $8 \mathrm{mM}$ の濃度で存在させると, 培地 $\mathrm{pH}_{0} 6.00$ に対し て細胞内 $\mathrm{pH}_{\mathrm{i}}$ は 7.26 になり, 細胞内 $\mathrm{pH}$ が 0.37 低下 するという実験結果がある ${ }^{(26)}$. 筆者らの測定結果によ ると, $\mathrm{pH}_{\mathrm{o}}$ が 5.7 で $10.4 \mathrm{mM}$ の酶酸ナトリウム存在下 では $\mathrm{pH}_{\mathrm{i}}$ は 7.1 であった。このとき，培地中では $90 \%$ の酢酸が解離型であるのに対し, 細胞質中では $99.6 \%$ の酢酸は非解離型となっているので, 培地に $10.4 \mathrm{mM}$ の䣷酸が存在した場合, 細胞内での濃度は $260 \mathrm{mM}$ にも なると計算される。酢酸アニオンの増加は細胞内アニオ ンプール中のグルタミン酸の流出をひき起こすが, グル タミン酸の流出でも調節できない場合には, 細胞内の電 位変動, それによるカチオンバランスの変動, さらには 膨圧上昇を招く。したがって, 有機酸の毒性の実体とは 細胞内 $\mathrm{pH}_{1}$ の低下, 細胞内における有機酸アニオンの 蓄積, 細胞内電位およびアニオン・カチオンバランスの 変動と細胞内溶質の増加による膨圧上昇, という複合効 果として理解できる.

グラム陰性細菌は細胞質膜の外側に外膜を有してい る. 外膜を構成している LPS の脂肪酸鎖は, 細胞質膜 のリン脂質と異なりすべてが飽和脂肪酸である．このた め, 外膜は細胞質膜と異なり流動性に乏しく, 疎水性物 質に対する強力な透過障壁となりうる ${ }^{(27)}$. この性質の ため, 疎水性の非解離型有機酸が外膜を通過するのは難 しく, 親水性のプロトン解離型が外膜に存在するポリン （porin）タンパク質で構成された非特異的なチャネル を介して通過する (図 4). ペリプラズムには負電荷の高 


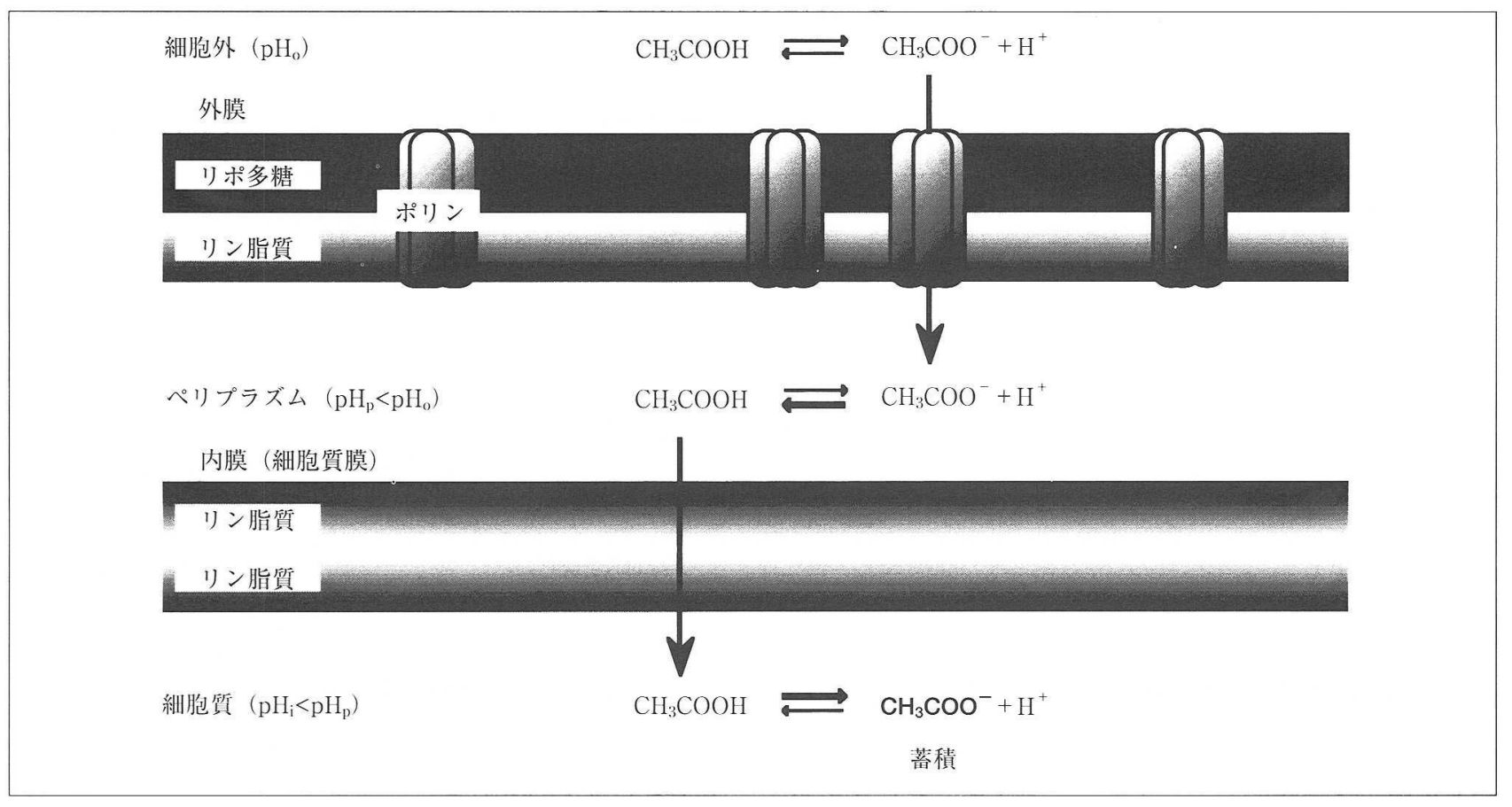

図 4 酢酸アニオンの細胞内への蓄積

分子（タンパク質）が存在するため，ドナン電位が生じ て抢り，ペリプラズムは菌体外よりも $\mathrm{pH}$ が低くなっ ているが，(外膜を移動できる溶質が少ないときは特に） 負電荷の分子の濃度は低めになる。このため，実際には 計算上よりも有機酸の細胞内への流入量を減らせるか, 少なくとも流入速度を遅らせることができる構造になっ ていると考えられる。

\section{0157 の有機酸耐性因子}

NGY9 に備わっていた有機酸耐性は, 酸耐性機構を含 む広範なストレス応答に深く関わると考えられる $\sigma^{\mathrm{s}}$ に は依存していなかった。したがって，この有機酸耐性機 構は，前節で紹介した既知の酸耐性機構の延長では説明 できないだろうと考えられた。そこで筆者らは，NGY9 の有機酸耐性に関与する因子を同定することを目的に，

NGY9に本来備わっていた有機酸耐性が低下してしま う変異株を取得することを試み，5つの変異株を分離 することに成功した(図 5)。取得した変異株に関して 変異遺伝子を同定したところ, 興味深いことに各変異は すべてLPSまたはECA（enterobacterial common antigen：腸内細菌共通抗原）の糖鎖合成・組み立てに関 わるものであった。結果として，各々の変異株は図 6 に 示したように，（I） ECA 糖鎖を欠くもの，（II）O 抗原 糖鎖を欠くもの，(III) それら両方を欠くもの，(IV)LPS の外部コアオリゴ多糖領域まで欠くもの，の 4 グループ に分類された。変異遺伝子の相補性試験により，正常な

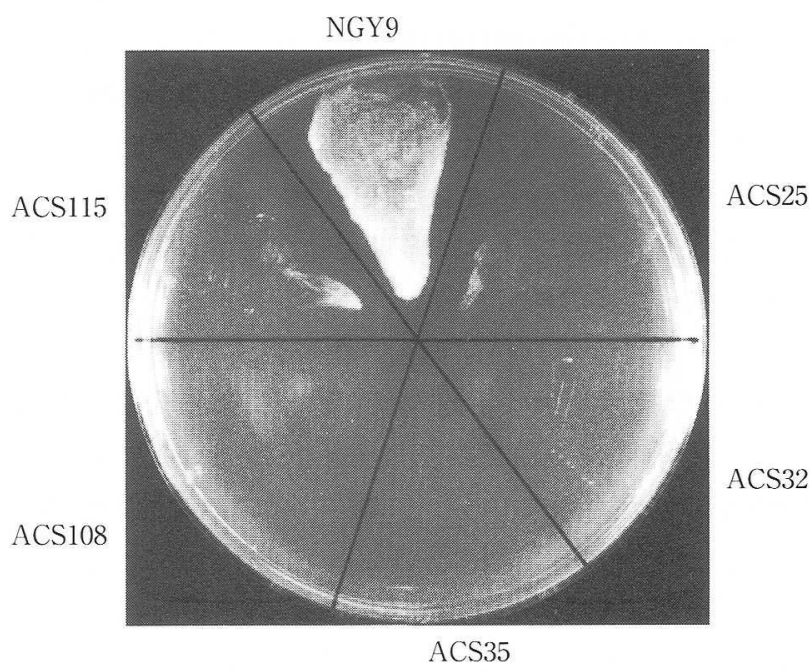

図 5 -0157 野生株と艺の酢酸感受性(ACS)変異株との酢 酸存在下での增殖能力の比較

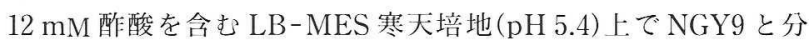
離した複数の ACS (acetic acid sensitive) 変異株を増殖させた結 果。

表層構造の回復とともに酢酸耐性も回復した。よって， 菌体表層の糖鎖が有機酸耐性に関わることが判明した。 ここで，最初に紹介した腸内細菌の表層構造を思い出し てほしい。グループ(IV) の変異株はいわゆる deep rough mutant のことで, 疎水性領域をもつ色素, 界面 活性剂, 抗生物質に非常に感受性になることがすでに報 告されている ${ }^{(28)}$ 。脂肪酸, フェノールなどの化合物にも 


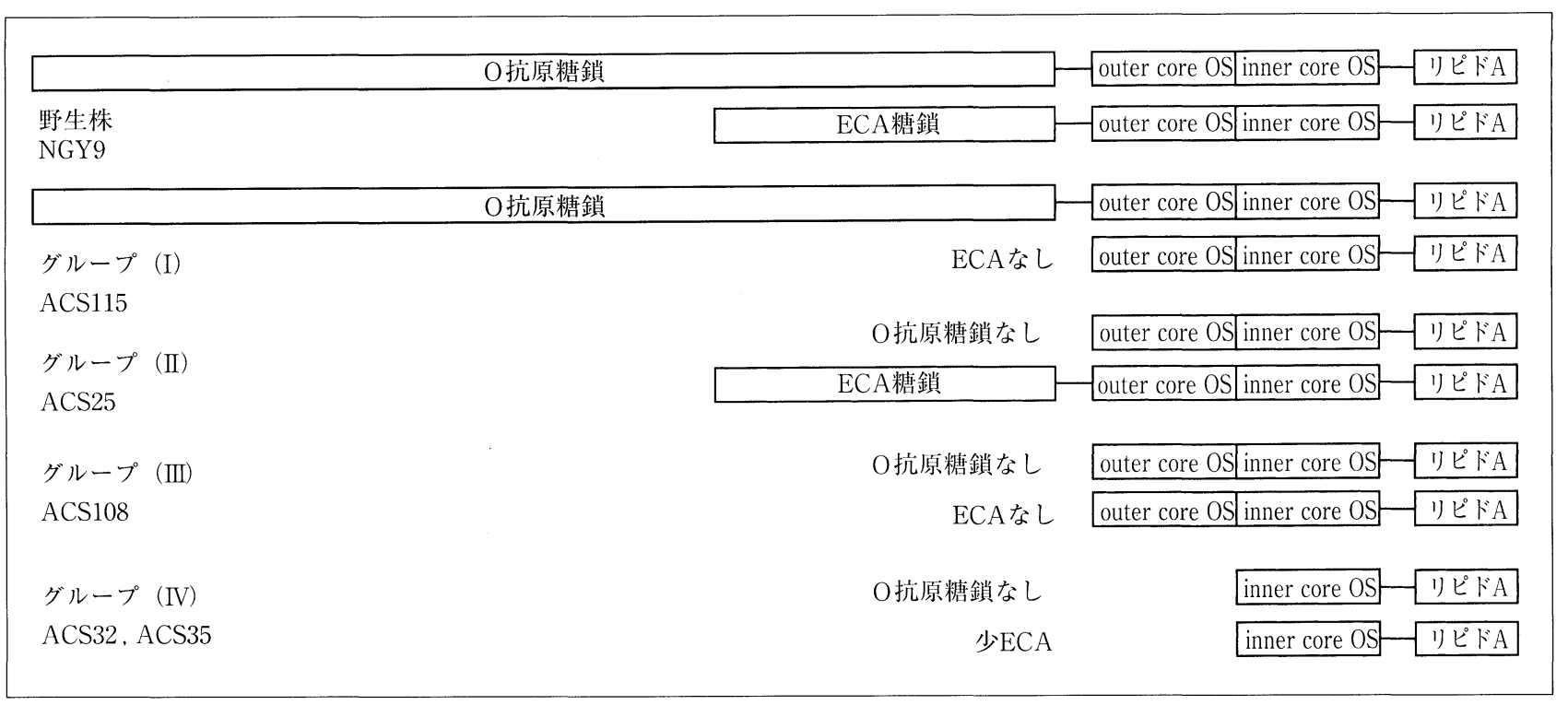

図 6 -NGY9 野生株と酢酸感受性(ACS)変異株における LPS (上) と ECA (下) 構造の模式図

感受性になることから，本来発揮される疎水性物質に対 する外膜の透過障壁が著しく機能しなくなっているもの と考えられている(28).この原因は LPSのコアオリゴ多 糖が不完全であるために, LPS どうしの相互作用，すな わち外膜の横方向の相互作用が弱くなっていることによ ると解釈されている。したがって，この変異株が酢酸に 対しても感受性になったのは妥当な結果と判断できる が，他の 3 つのグループは LPS のコアオリゴ多糖は正 常であり，外部コアオリゴ多糖に結合している糖鎖部分 のみを失った変異株である。

グループ (II) は O 抗原糖鎖を欠いた変異株であるが, $\mathrm{O} 157$ の $\mathrm{O}$ 抗原糖鎖は 4 糖の繰り返しによる分岐鎖を含 まない直鎖状の多糖であることが, Perryらによって 1986 年に決定されている ${ }^{(29)}$. 報告された $\mathrm{O}$ 抗原糖鎖の 構造は[-3)- $\alpha$-D-GalNAc-(1-2)- $\alpha$-D-PerNAc-(1-3)$\alpha-\mathrm{L}-\mathrm{Fuc}-(1-4)-\beta-\mathrm{D}-\mathrm{Glc}(1-]_{n}$ を単位とする繰り返し 構造で構成されていた。ここで, GalNAc は $N$-アセチ ルグルコサミン, PerNAc はぺロサミン, Fuc はフコ ース，Glc はグルコースのことである．この繰り返し配 列の中に，D-ペロサミンが含まれるが，この糖の存在 が $\mathrm{O} 157$ に独特の抗原性をもたらしていることがわかっ ている．この結果は，O157 抗原糖鎖が O157 自身に酢 酸耐性を付与することを意味しており，実験室株 K12 ( $\mathrm{O}$ 抗原糖鎖をもっていない) と臨床分離株 $\mathrm{O} 157$ の 有機酸而性の違いの一つは, $\mathrm{O}$ 抗原糖鎖の有無にあるこ とがわかった。糖鎖の付加により外膜表層における酢酸 との親和性が妨げられるものと考えられるが, 有機酸耐 性に関わる理由はまだ解明されていない，O抗原糖鎖の 中に電荷をもつ糖は含まれていないことから，少なくと
もこの部分での電気的中和または反発が酢酸耐性に関 与しているわけではない。筆者らは, サルモネラ菌でも LPS の O 抗原糖鎖部分を欠くことで有機酸而性が低下 することを確認しているが, O157 における $\mathrm{O}$ 抗原糖鎖 よりも有機酸耐性に寄与する程度は低いことが観察され た. 糖鎖の種類ごとに有機酸耐性に違いが生じるかどう かは興味深い疑問であるが, 現時点ではまだ不明であ る.いずれにせよ，一般に $\mathrm{O}$ 抗原糖鎖を失った腸内細 菌は病原性をも同時に失う. $\mathrm{O}$ 抗原糖鎖は, 親水性の長 い鎖状構造（通常約 4 糖を 1〜40 回リピート）とその糖 鎖配列の菌種間・内での多様性に特徵がある. よってそ の働きとして, (1)細胞最外殼に親水性を付与し乾燥から 守ること, (2)疎水性の化合物の接近を妨げること, (3)バ クテリオファージの吸着を阻止すること, (4)宿主のファ ゴサイトーシスに対して防御すること, (5)完全な外膜構 造体を維持し安定化させること, 6)抗原多様性を生み出 せること, などが挙げられる。この結果は, O 抗原が有 機酸耐性を付与することはもとより, 有機酸が存在する 腸管での増殖そのものに $\mathrm{O}$ 抗原が重要であることを示 唆して抢り, O 抗原が病原性に深く関わることの一端を 明らかにできたものと考えている。

グループ ( I ) は ECA 糖鎖を失った変異である. ECA も菌体表層の糖脂質であり, 腸内細菌共通抗原という名 の通り, 腸内細菌に特有かつ普遍的に存在している. LPS の $\mathrm{O}$ 抗原糖鎖が菌種間のみならず菌種内でも変 化に富んでいるのに対し, ECAの糖鎖は共通であり, [-3)- $\alpha$-D-Fuc4NAc-(1-4)- $\beta$-D-ManNAcA- (1-4)$\alpha-\mathrm{D}-\mathrm{GlcNAc}(1-]_{n}$ の繰り返し構造をとっている ${ }^{(30)}$. こ こで, D-Fuc 4 NAc は 4-アセトアミド-4,6-ジデオキ 
シ-D-ガラクトース, D-ManNAcA は N-アセチル-Dマンノサミヌロン酸, D-GlcNAc は $N$-アセチル-D-グ ルコサミン（70\%は C-6 が O-アセチル化している）の ことである，このリピート内には，N-アセチル-D-マ ンノサミヌロン酸が含まれているので，酸性多糖とな る. ECA 糖鎖はジアシルグリセロールリン酸に共有結 合し，外膜脂質に埋め込まれているものも存在するが， 多くの ECA 糖鎖は $\mathrm{O}$ 抗原糖鎖同様に LPS のコアオリ ゴ糖に共有結合している，腸内細菌すべてが ECA 糖鎖 を保有していて，なおかつその糖鎖配列はすべての腸内 細菌で保存されていることより，ECA が特に腸内細菌 にとって重要で普遍的な役割がある可能性が予想される が,これまでに ECAの生理的役割は不明であった。今 回の，ECA 糖鎖のみが失われることで有機酸耐性が低 下した結果から，ECA が有機酸耐性に関わることが判 明した。ECA が有機酸耐性に関与する原因は不明であ るが，腸管を住処とする細菌に ECA が普遍的に備わっ ていることは，腸管においては有機酸存在下での増殖能 力が重要であることを逆に意味していると考えることも できよう。

*

腸内細菌にとって腸管は増殖が可能な場であり，常 在・寄生するにせよ，定着・感染するにせよ，腸管での 増殖能力は重要な要素になりうる．腸管は酸素に乏しい ので，エネルギー生成のために糖の発酵に依存するとこ ろが大きい．大部分の腸内細菌は混合酸発酵を行なうの で，最終産物として有機酸が菌体外に放出される。この 有機酸に抗して増殖を効率的に行なうことが腸内におけ る優勢種となる条件になるであろう。腸内細菌は細胞質 膜の外側に外膜を有しており，外膜には糖鎖が付加され ている。この糖鎖の存在により有機酸に対する耐性を獲 得していた．これは，腸内細菌表層に糖鎖が存在する理 由の一端が判明したものと考えている(31).

\section{文献}

1) J. Konowalchuk, J.I. Speirs \& S. Stavric : Infect Immun., 18, 775 (1977)

2) H. Kobayashi, J. Shimada, M. Nakazawa, T. Morozumi, T. Pohjanvirta, S. Pelkonen \& K. Yamamoto: Appl. Environ. Microbiol., 67, 484 (2001).

3) K.A. Glass, J.M. Loeffelholz, J.P. Ford \& M.P. Doyle : Appl. Environ. Microbiol., 43, 2513 (1992).

4) T. Zhao \& M.P. Doyle : J. Food Prot., 43, 780 (1994).

5) T. Zhao, M.P. Doyle \& R.E. Besser: Appl. Environ. Microbiol., 59, 2526 (1993).

6) P.L. Small \& S.R. Waterman : Trends Microbiol., 6, 214 (1998).
7) M.P. Castanie-Cornet, T.A. Penfound, D. Smith, J.F. Elliott \& J.W. Foster : J. Bacteriol., 181, 3525 (1999).

8) R. Iyer, T.M. Iverson, A. Accardi \& C. Miller : Nature, 419, 715 (2002).

9) M. Takayama, T. Ohyama, K. Igarashi \& H. Kobayashi : Mol. Microbiol., 11, 913 (1994).

10) H. Kobayashi : Recent Res. Devel. Microbiology, 6, 379 (2002).

11) T. Yoshida, C. Ueguchi \& T. Mizuno : J. Bacteriol., 175, 7747 (1993).

12) K.S. Gajiwala \& S.K. Burley : J. Mol. Biol., 295, 605 (2000).

13) F. Yang, K.R. Gustafson, M.R. Boyd \& A. Wlodawer : Nat. Struct. Biol., 5, 763 (1998).

14) D. De Biase, A. Tramonti, F. Bossa \& P. Visca: Mol. Microbiol., 32, 1198 (1999).

15) R. Wagner: "Transcription Regulation in Prokaryotes", Oxford University Press, New York, 2000, p.40.

16) R. Hengge-Aronis : J. Mol. Microbiol. Biotechnol., 4, 341 (2002).

17) N. Masuda \& G.M. Church : Mol. Microbiol., 48, 699 (2003).

18) Z. Ma, H. Richard, D.L. Tucker, T. Conway \& J.W. Foster: J. Bacteriol., 184, 7001 (2002).

19) A. Tramonti, P. Visca, M. De Canio, M. Falconi \& D. De Biase: J. Bacteriol., 184, 603 (2002).

20) A. Spory, A. Bosserhoff, C. von Rhein, W. Goebel \& A. Ludwig: J. Bacteriol., 184, 3549 (2002).

21) C.J. Herbelin, S.C. Chirillo, K.A. Melnick \& T.S. Whittam : J. Bacteriol., 182, 5381 (2000).

22) E. Martinez-Garcia, A. Tormo \& J.M. Navarro-Llorens : Curr. Microbiol., 46, 365 (2003).

23) M.L. Kotewicz, E.W. Brown, J. Eugene LeClerc \& T.A. Cebula: Trends Microbiol., 11, 2 (2003).

24) M.L. Kotewicz, B. Li, D.D. Levy, J.E. LeClerc, A.W. Shifflet \& T.A. Cebula : Microbiology, 148, 2531 (2000).

25) T. Horii, S. Barua, T. Kimura, S. Kasugai, K. Sato, K. Shibayama et al. : Microbiol. Immunol., 43, 871 (1998).

26) A.J. Roe, D. McLaggan, I. Davidson, C. O’Byrne \& I.R. Booth : J. Bacteriol., 180, 767 (1998).

27) H. Nikaido \& M. Vaara: Microbiol. Rev., 43, 1 (1985).

28) H. Nikaido: "Escherichia coli and Salmonella: Cellular and Molecular Biology", ed. by F.C. Neidhardt et al., American Society for Microbiology Press, Washington, DC, 1996, p.29.

29) M.B. Perry, L. MacLean \& D.W. Griffith : Biochem. Cell Biol., 43, 21 (1986).

30) P.D. Rick \& R.P. Silver: "Escherichia coli and Salmonella: Cellular and Molecular Biology" ed. by F.C. Neidhardt et al., American Society for Microbiology Press, Washington, DC, 1996, p.104.

31) S. Barua, T. Yamashino, T. Hasegawa, K. Yokoyama, K. Torii \& M. Ohta: Mol. Microbiol., 43, 629 (2002). 